\title{
Gasparo (Della) Vecchia, Architecture, and Russia
}

In 1697 Peter the Great sent a group of so-called navigatory to study navigation, mathematics, and military architecture in Venice; there can be little doubt that this journey, which also included several trips to other regions of the Italian peninsula, represented a cultural breakthrough in mutual awareness for both Russians and Italians. Evidence, partly uncovered by the research carried out by Evgenij Šmurlo in Italy, shows that local administrators and diplomats had great interest in helping and collaborating with the Russian nobles, who to their eyes represented a young and still little known nation. The Russians were, in fact, charged with great expectations and received in solemn audience by rulers of numerous Italian states. Once back in Russia, some wrote down what they saw and experienced, giving more or less detailed records of their travels which are full of Italianisms and resemble the statejnye spiski usually written by ambassadors returning from their missions abroad. In the navigatory's writings, one reads, for instance, of their stops along the routes in Italy, Dalmatia, and Malta; famous local sites, monuments, important personalities, and people from various occupations: all these details were important data proving that the envoy had carried out his task properly and was able to pass on the information to future travellers. The navigatory, many of whom belonged to powerful families of the Russian aristocracy, were often experienced men with established careers and occupied important roles in the military and civil hierarchy. Because of their acquired expertise, their knowledge of foreign languages, and the important relations established abroad, some (Petr A. Tolstoj, Grigorij F. Dolgorukov, Boris I. Kurakin, and Petr Al. Golicyn) were appointed ambassadors and sent to European capital cities; others, thanks to the skills developed during the two years of study and training, gained the tsar's trust and became part of his entourage of collaborators and advisers.

If on the one hand their professional and representative role has been discussed, on the other hand their involvement and participation in the Venetian and Italian context, their connections, and adherence to local customs and traditions remain to be understood. The fact that the sources available omit, fully or partly, this side of the story suggests that in Italy the Russians, unlike some decades earlier (Di Salvo 1997), were no longer an ex-

* I should like to express my gratitude to the Biblioteca Comunale of Treviso and to Dr. Monia Bottaro for providing a copy of manuscript No. 393 belonging to the Library and the authorization to reproduce parts of it. 
otic, instantly-recognizable phenomenon: the Russians in Rome are said to dress in French style ("rivestiti alla franzese", Šmurlo 1903: 32I), whereas in Vita e viaggi ('Life and travels') Filippo Balatri recalls that his patron, prince Petr A. Golicyn, acquired in Italy a habit of shaving, and unlike his compatriots did not experience a cultural shock when the tsar imposed men to have their beard cut. The navigatory became certainly acquainted with such local social conventions as meetings and assemblies, which Peter the Great later introduced in Russia, and with some unusual realia, which included, but were not limited to, food and dress. We learn, for instance, that Petr Golicyn was affected by hypochondria, which "pushed him to become acquainted with all doctors in Italy" (a profession still somewhat rare in Muscovy); he returned home "supplied with several instructions about life style, recipes, and drugs to combine into ointments, [and] having one of his servant being instructed as to how to manipulate these" (Balatri 2020: 42).

In order to fully appreciate the process of cultural transfer and the dynamics activated in Muscovy by the navigatory's individual experience, it would be useful to examine their connections, facilitated by their familiarity with the Italian language, and their teachers' personalities more closely. Among the latter was Gasparo Della (or Dalla) Vecchia (16531735)', who has been so far neglected in this context since little is known about his biography. Because of the current difficulties with carrying out archival work and accessing records, I have not been able to investigate some key aspects about his life and work in detail; it remains to be established, for instance, whether he was nominated in charge of the training of the Russian students formally, as it seems, by the government of the Serenissima, or whether he had informal relationships only with some of them.

The main facts on Gasparo's life are available in the Biographical Dictionary of the Italians in appendix to the entry about his father (Aikema 1989); Pietro Della Vecchia (I602/03-1678), also known as "Muttoni", was, like his wife Clorinda Régnier, a painter, and also an art conservator and mediator. Gasparo had an eclectic education and trained as a painter at his father's workshop, which he later inherited (Lucchese 20II: 297, n. I): the best documented part of his artistic activity dates back to the I7IOs in Istria, but it must be acknowledged that he devoted himself to several other fields. A manuscript of a treatise on music (Pratica di musica moderna, I7II) penned by Gasparo Della Vecchia is held by the Biblioteca Marciana in Venice; in 1714 he became "mathematician of the Serenissima" (Aikema 1989) and later published a work on nautical topics (Vecchia 1729) - an interest which, if he had cultivated it earlier, could justify his acquaintance with the navigatory. It looks plausible that Vincenzo Coronelli, the famous Venetian cosmographer and cartographer appointed by the Venetian Republic to supervise the Russians' studies (Šmurlo 1903: 278-280)², may have been an important intermediary between Gasparo and the Rus-

In the primary sources known to us, Gasparo, like his father (Aikema 1984: 79) before him, signed himself as "Vecchia".

2 Coronelli ("Karonelli"), "a master of mathematics and cosmography and other alike sciences”, is mentioned in the travel diary by Petr A. Tolstoj (I992: III). 
sian students. Some years earlier, in his Viaggi, Coronelli writes: "Fumiani's [Giovanni Antonio] painting and Gasparo Vecchia's in [the fields of] perspective and architecture are becoming renowned" (Coronelli 1697: 23-24). Scholars have recently remarked on the attention given to perspective representation in Gasparo's painting (Lucchese 20II: 297, n. 28); what follows here confirms his interest in the fields of architecture and artistic theory as suggested by Aikema (1989). It seems that Della Vecchia was the inventor of some of the etchings by Alessandro Dalla Via, who had started his career in the Academy of the Argonauts, founded in 1684 by Coronelli, "producing engravings to be inserted into the works authored by him" (Donaggio 2017: 47). Gasparo's name is found in several Venetian landscape paintings published in Coronelli's volumes, such as Corso geografico universale (Venice 1692) and Singolarità di Venezia (Venice 1708)3.

It seems reasonable, considering Coronelli's regard for the versatile artist, to assume that Della Vecchia owed to him his involvement in training the Russian students; there is no doubt that the title of Architektura cyvilnaja (see the incipit given below), a manuscript work held by the Archive of Ancient Acts (RGADA) in Moscow and known to scholars, refers to Della Vecchia ${ }^{4}$. Leaving aside for another occasion the linguistic analysis of this text, in this article I shall point out some features which help to highlight the role of cultural mediator played by Gasparo during the time spent in Venice by the navigatory.

The opening words of Dolgorukov's Architektura cyvilnaja are the following: "Architektura cyvilnaja vybrana is Paladiusa slavnago architekta $i$ is ynych" mnogich" architektov slavnych" ot matematika i architekta Kašpora Vekia pisana v Venecii léta I $69 g$ godu meseca sentiabrja. Učeniem" i tšcaniem" buduči tamo gospodina knjazja dolgorukova. A po ruskomu kaljandaru 7206 godu". This treatise has been categorised as "translation" in the monumental work by P. Pekarskij (I862, I: 220) which surveys the state of science and literature under Peter the Great; Pekarskij, who transcribes the frontispiece inaccurately, dedicates only few lines to this text. On a similar note, V. Šilkov (1955: 89) defines the treatise as a "translation of Palladio's selected passages". It was not until the 1970 s that the manuscript was analysed more thoroughly by A.A. Tic who, as an historian of architecture, has contextualised the work within the Italian tradition of theoretical treatises on Renaissance architecture from Palladio to Vignola. Tic contends that Architektura cyvilnaja should be attributed to Vasilij Lukič Dolgorukov; there were three persons at the time in Venice bearing this surname, as it demonstrated by Dm. and I. Gouzévitch in a forthcoming article (Guzevič, forthcoming), where they attribute the manuscript to Grigorij Fedorovič Dolgorukov and also discuss the apparent problem with the date 1699 (by then, the navigatory had left Venice). Here I shall limit myself to examine the structure of the Russian treatise.

3 See the catalogue by V. Donaggio (2017), pp. 90, 93, 94, and 127.

4 RGADA (f. I8I, ed. chr. 258). The manuscript is available online at: <http://www.hrampodmoklovo.ru/data/2014/02/02/1234571901/Архитектура\%2оцывилная\%201699.pdf> (Last access: May 202I). 
Tic's overall assessment of Architektura cyvilnaja is obvious since the very beginning of his analysis, when he argues that this is "an independent work, largely based on compilation" (Tic 1968: 18) and, in line with the then common trend of Soviet publications, he claims this work as part of the Russian cultural heritage (and source of national pride) by adding: "The specific characteristics of the architectonic thought and the nature of presentation leave no room for doubt that the author must have been Russian, and most likely Dolgorukov himself (Tic 1968: 30), and that therefore we are dealing with "the earliest Russian treatise [on architecture] to date" (Ibidem). Tic's peremptory assessment is not confirmed by facts, yet his analysis remains valuable, especially because he has been the first to compare in detail the subject matter expounded in the Russian treatise with Palladio's and Vignola's theories. More recent investigations include those by F. Rossi (2009 and 20IO), who must be credited for having explored Dolgorukov's work within the history of Russian architecture.

Tic's observations have influenced all subsequent studies on the topic, and it thus becomes necessary to remove some of the misconceptions due to his scanty knowledge of the history of the Russian language, and which seem to be ineradicable in present-day scholarly literature. The scholar correctly noted the presence of several Polonisms in Architektura cyvilnaja, but did not give examples: one might quote such words as ličba (Pol. liczba, 'number'), priklad (Pol. przyktad, 'example'), treba (Pol. trzeba, 'one must'), or Dolgorukov's particular use of some terms, for instance povinno to mean Pol. powinno, 'it should'. It must be borne in mind, though, that many of these terms, and the particular ways they were employed, were present in ancient Russian and are recorded in historical dictionaries; nor can one neglect the relevant cultural fact that the seventeenth-century Russian upper class, to which Dolgorukov belonged, was, in fact, widely familiar with Polish. Tic misunderstood the sentence "а посполите копаютъ рвы глубоко на шестую долю вышины того здания" and similar other sentences in the manuscript, where the Polonism pospolite (Polish pospolicie, 'commonly, generally') has been taken to mean 'the Poles's, or perhaps as an adverb, 'in the Polish way', despite the fact that the term appears as an entry in the historical dictionaries of Russian. On the basis of this misinterpretation, Tic states that in the treatise some instructions "are integrated with data drawn from the Polish building construction practice" (Tic 1968:27) and, following his authority, scholarly publications keep referring to phantom "Polish" or even "Polish-Lithuanian treatises" employed (along with Italian sources) by Dolgorukov.

The title itself of Architektura cyvilnaja states clearly enough the role played by different actors involved in the making of the treatise: written by Dolgorukov during his stay in Venice, it is a selection 'from' ( $i z$ ) Palladio and other prominent architects 'prepared

5 Since Architektura cyvilnaja has received little attention from linguists and experts in the history of the Russian language, there has never been a critical evaluation of Tic's reading and the notion of "Polish treatises" has been regarded as useful and is recorded also in studies by Italian scholars (Pesenti 2003: 256; Rossi 2010: 231). 
by' (ot retains here the old agentive function and is not a variant of $i z$, as some seem to believe) Gasparo Vecchia. Notably, showing a general lack of interest in Dolgorukov's opening words, scholars have so far dismissed the importance of Dolgorukov's account about Vecchia's contribution to Architektura cyvilnaja. Some have put forward the names of Gaspare De Vecchi from Rome and others the Venetian Antonio Gaspari, while the Venetian Gasparo Della Vecchia has not been seriously considered, partly because of his relative unknown status, and partly because the scant biographical details tend to overlook his interests in mathematics and architecture.

Nevertheless an autograph manuscript signed by Gasparo Della Vecchia, which is entitled Breve trattato d'architettura civile, is held by the Biblioteca Comunale of Treviso. It does not provide the same text which was used by Dolgorukov for his translation, since it was written after the Russians' departure from Venice (the last page bears the date 30 May 1725); yet its content is highly interesting, and an analysis of this surviving witness enables us to ascertain the nature of Della Vecchia's role in the work of his Russian student. Breve trattato is a didactic work, encyclopaedic in nature in that it collects and summarises existing knowledge; repetitions and short digressions either to explain the origin of some terms (see, for instance, "the pulvino is a kind of pillow worn by widows for ornament", $f$. 25 ) or to make the exposition more engaging (for instance, the Ionic "can be defined as the female of the architectural orders, its capital being rather small in size", f. 25) are common. These instructions are but a summary of the first and the beginning of the second book by Palladio, with the difference (already remarked by Tic in respect to Dolgorukov's text) that the chapters dedicated to building materials (On woods, On stones, On metals, and so forth), soil quality, and foundations occur not at the beginning, but at the very end of the work. One also finds references to "great" and "renowned" architects, such as Vitruvius and Palladio, but in terms of the theory of architectural proportion Della Vecchia declares to follow the rules set down by Vignola, "very much accredited" (f. 2). Unlike his Renaissance sources, Gasparo rarely mentions Italian masterpieces of architecture as an example, which demonstrates that his intention was to satisfy basic learning needs and, more importantly, to focus on practical skills: he explains the use of the concept of 'module' and the details and terminology of the five orders of classical architecture, elucidating how to distinguish between the components and to measure them. While on the one hand Palladio and Vignola dedicate brief chapters to each architectural order and provide accompanying illustrations, the Breve trattato by Della Vecchia repeats in a scholastic manner the subdivision into single elements for each of the classical orders of architecture. The attention to detail is not merely descriptive; the aim is rather to show 'how to make' things and the subject matter is organised around key architectural elements, such as the column, pedestal base, Minute members of the capital, Minute members of the pedestal base, Minute ornaments of the column, Intercolumn, and Loggias, which are repeated for each order.

The same expository arrangement was adopted by Dolgorukov, in whose work one finds meticulous elementary and practical descriptions; he explains how to draw a column by first inserting pins into two different parts of the sheet of paper, then place the ruler 
(ryga: cf. Italian riga) on the paper, move the rule in front of the pins, and finally trace a line (f. 6). Despite some obvious differences (Dolgorukov employs a more verbose expository style), it cannot be denied that Della Vecchias treatise has been greatly influential to the structure of the Russian's work. Tic (1968: 27) had clearly perceived that in the chapters on vaults and the height of rooms, where Dolgorukov added technical details which were clearly not drawn from Palladio's work, he must have used pre-existing "material of the $17^{\text {th }}$ century Roman architect and mathematician Gaspare Vecchi", mentioned in the title of the work. Apart from the obvious mistake made in identifying the Italian author, Tic rightly observed that Architektura cyvilnaja departs in several aspects from Palladio's work: for instance, he observes that Dolgorukov heavily relies on Vignola's ideas (a fact also underlined by Rossi 2009), which Tic interprets as an attempt to make new concepts available to a potential Russian readership, most likely building experts used to working in a completely different environment. The Soviet scholar could not have been aware that the innovations proposed by Dolgorukov were actually drawn from Della Vecchia's work; the same holds true for the comparison between a column and a tree (because "in architecture we should imitate nature in everything we do", according to Vitruvius' conception) and the simplification of Vitruvius' principle of 'order', which Tic (1968: 23) attributes instead to Dolgorukov as if it were his original innovation. Compare, for instance: "Рят нъ что иное есть токмо чтобы всь части зАания были зАбланы добрым порядкомъ, то есть чтобы пустые мъста были сходныя с пустыми мъстами а гмухия бы мъста сходны с глухими местами также чтобы то всђ что есть зАђ аано на правой сторонђ также повинно здъцать и на мевой сторонь, такъ какъ писано выше" (f. 76) and the chapter Precetti di architettura (The fundamentals of architecture) in Della Vecchia: "Order, for the parts should correspond with the whole, so empty elements such as doors and windows with [other] empty elements, and full elements with [other] full elements, and everything which we make on the right side must harmonise with what is on the left side, imitating Nature itself”. Another example concerns розмеръ ('arrangement'): “нъ что иное есть токмо старатьца чтобы всь каморы здания также саме то есть сени также модзи то есть проходы и иныя части того здания были 6 розмьрены хорошо" (f. 76 ); in this regard, Della Vecchia states: "Arrangement, for everything should be well arranged, for instance the rooms, gates, loggias, and all the comforts, so that everything is in its right place". Moreover, the chapter entitled $O$ skladanii architektury, which Tic (1968:23) considers additional evidence "of methodological autonomy in the presentation of the principles of the architectural orders", actually rephrases, in a more wordy and detailed way, the chapter Notandi nella composizione delli ordini d'architettura (Notes on the composition of the orders of architecture), where Della Vecchia expounds the principles to apply when juxtaposing in one building elements belonging to different architectural orders.

I will not provide further passages to illustrate the debt of gratitude due to his Venetian teacher and acknowledged by prince Dolgorukov himself. The vocabulary used in the Russian treatise, which follows almost entirely the original Italian with no morphological adaptations, is a topic for future work. It is worth noting that the attempt (see the Russian 
passage mentioned above) to render Italian sale into seni has been interpreted as yet another proof of Russification by Tic (1968: 25-26), who believes the term refers to the Russian $i z b y$ and the traditional wooden peasants' houses, where seni was the entryway.

What has been so far presented in this paper helps to shed some light on the relationship between Gasparo and his student. Breve trattato d'architettura civile obviously was not the very work used by the Russian, but must have grown from another text composed earlier and partly identical to Breve trattato, as there is a clear correspondence between Dolgorukov's work and the surviving manuscript containing Breve trattato. Della Vecchia based his compilation on Palladio's first book and incorporated lengthy reference material from Vignola's Regola and allusions to the principles expounded by Vitruvius, thus producing a guide, a source text to introduce and gradually train the student to understand and then apply the principles of the five orders of classical architecture and building construction. It is likely that theoretical knowledge was complemented by practical exercises with ruler and compass - such a pragmatic approach is fully reflected in the Russian work by Dolgorukov, who was attentive to the role of acculturation and knowledge transmission which it would play in Russia, in light of the transformations introduced by Peter the Great.

Architektura cyvilnaja presents numerous drawings: some reproduce Palladio's, although in a more basic way, while others are original and illustrate individual architectural elements with relating measurements and brief descriptions; I agree with Tic that the drawings, arranged on the right side of the sheet in respect to the written text, were prepared in order to visually accompany the verbal explanations, as demonstrated by the use of cross-referenced letters and numbers. Some of the illustrations present words, often blurred, in Italian written with a pencil, for instance, on f. 19, and on f. 31, where the Russian correspondent term has been written over the Italian medaglione (medallion); on f. 39, which is given below (see FIGURE I, on the right), the handwriting is without any doubt Della Vecchias. One finds a number of similar drawings in the treatises by Della Vecchia and Dolgorukov; in the work by the Russian, these are more accurate and occupy a whole page, as is the case of the drawing given below in FIGURE 2; but I shall leave a more detailed comparative study of the illustrations to specialists. It is not possible, without access to the original manuscript, to establish with any certainty whether only the drawings or also the transcription, which was made most likely by one or perhaps two copyists, of Architektura cyvilnaja were realised in Italy.

We know too little of Gasparo's life to be able to explain the reasons why in 1725 in Venice he recopied (or elaborated?) the Breve trattato, where the signature "Gasparo Vecchia" is preceded by the title "Director": we can speculate that he may have continued teaching the principles of civil architecture by using the notes he had written some years earlier, or that at some point he decided to go back to the same text for other reasons. The comparative analysis presented above suggests that, if the manuscript represents an elaboration of an earlier work, no drastic modifications were made, given the numerous similarities between Dolgorukov's work and the extant witness of Breve trattato. Archival research in Venice will be needed before we adequately address important questions which still re- 

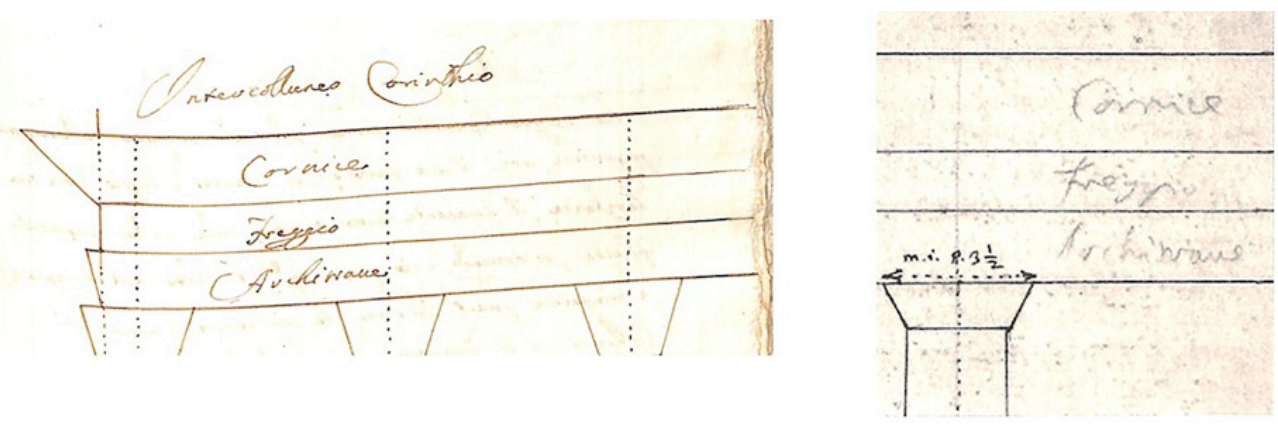

FIGURE I.

On the left: Treviso, Biblioteca Comunale, MS 393, Breve trattato by Della Vecchia (the page is not numbered). On the right: the same Italian words in Dolgorukov's Architektura cyvilnaja, f. 39.

main open: for instance, it would be interesting to understand whether Gasparo received some other assignments by the Republic of Venice and why he held the title of "Director". After the experience with the navigatory, Russia did not disappear from Della Vecchia's life, as an autograph letter reveals; dated Io March 1715, it is held among Peter the First's books and papers which, following his death, were donated to the Library of the new-born Academy of Sciences (today BAN, St Petersburg). The catalogue of the tsar's library lists the letter (n. 842 in Bobrova 1976: 100) among the manuscripts in foreign languages and attributes it to Gasparo "Vacchia", misinterpreting the vowel "e" due to the author's handwriting. Here the Venetian artist signed the letter with the wording "Geographo et Astronomo Veneto" " $:$ whether or not this was an official title, it certainly added authority to the content. There is a coloured drawing introducing the letter which depicts the terrestrial globe and is accompanied by the heading Idea di Giardino Imperiale e Monarci$\mathrm{cho}^{7}$ (the last term is spelled in a way which is found in other writings by Della Vecchia; the same holds true for consonant gemination and reduction, common among speakers from the north-eastern Italian region of Veneto). The garden planning proposal is original and ingenious, and after a high-flown introduction, is so expressed: "più bella, amirabile, né più concepita idea può darsi, che in piano veder l'espanso di questo mondo transformato con ingegnosa metamorfosi in giardino, e nel passagio di quello aquistar la notitia delitiosa di tutto il mondo geografico" ${ }^{8}$ (f. 2); the author emphasises that the garden project would provide the opportunity to enjoy and get to know what in normal circumstances was not

6 English translation: "Venetian Geographer and Astronomer".

7 "An Imperial and Monarchic Garden Project".

8 "No more beautiful, admirable, or better conceived idea can there be than to see this world on a flat plane transformed into a garden with ingenious metamorphosis, and while walking through it to acquire delightful knowledge of the whole world". 

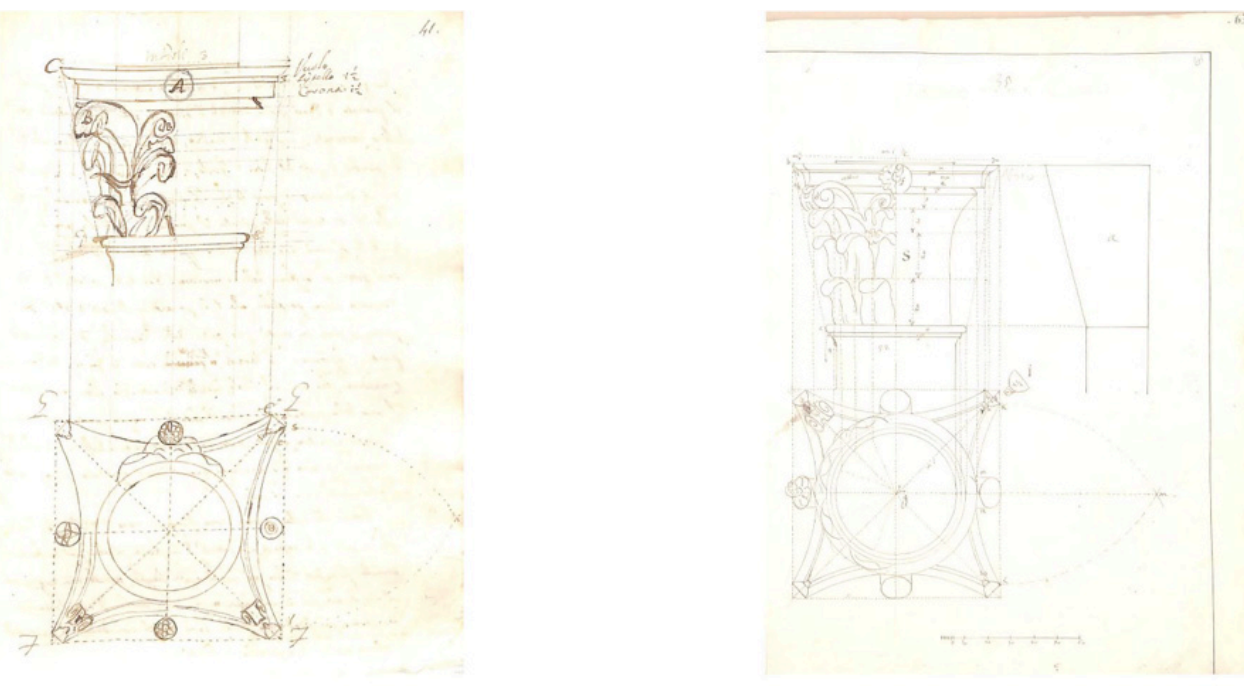

FIGURE 2.

Corinthian capital (on the left: Breve trattato, f. 4I; on the right: Architektura cyvilnaja, f. 6I).

easily accessible or dangerous. Aware of the tsar's interest in ships and navigation, Gasparo explains that: "L'oceano ed altri mari darano la delitia di peschiere con navigli propri assegnati ad ogni natione, conservati quelli ne' porti principali di quelle regioni, con il navigar tal oceano si haverà notitia di tutti li porti principali e particolari del mondo, loro sitto e distanze con sue particolarità" (f. 3$)^{9}$.

Della Vecchia tries in the same way to acquaint the visitors with the Earth by way of beautiful fountains evoking rivers and streams; "le cità metropoli saranno dinotate con statue con armi ed altri particolari del loro Sovrano", while "boschi e selve servirano per delitiosi parchi o broli e ritiri con ombre, con fiere in essi secondo la proprietà del paese, quali non potendo forse esser naturali si effigeranno in marmo" (f. 4$)^{10}$. The division of different countries can be achieved by "delitiosi comparti di giardino con entro essi dissegni di parterra all'uso

9 "The oceans and other high seas will provide the delight of fish-ponds, with vessels, belonging to different nations and anchored at the main ports of different regions; by sailing across the ocean one will get to know all the main ports and acquire knowledge about the world, places, distances, and all other details".

10 "Statues with weapons and other local rulers' details will remind of world capitals", while "woods and forests will be identified by parks, orchards, and retreats providing shade, with animals from different countries, which will be sculptured in marble, being unlikely for them to be always real". 
del paese con ivi fiori, frutti ed ornamenti secondo richiede la particolare regione" ${ }^{\text {"II }}$, in order to acquire the knowledge of "la scienza tanto utile e necessaria della geografia" ${ }^{12}$, and enjoy the wonders of the world, "mai compilate da mente umana, se non monarcica" (f. 4$)^{13}$.

We know neither the tsar's reaction to this letter nor its aftermath: the project was clearly never realised, despite the fact that Della Vecchia proved to have understood the utilitarian and pedagogical nature of Peter's initiatives, his extensive reforms, and the geometric spirit and moving force behind the city planning envisaged by the tsar for the new Russian capital. The Venetian must have grasped some aspects of Peter's psychological makeup during his association with Dolgorukov; but it cannot be excluded that, as Russian agents were sent to Venice to buy pieces of art (Androsov 2003: 17), Gasparo may have played some intermediary role, like his father long before. The envoys sent to Venice by Peter the First had also the task of collecting statues to decorate the Winter Garden in St Petersburg, and the didactic role which he attributed to the decorative aspects of garden design and landscape architecture was probably well-known in the Italian city. The project proposed by Della Vecchia was perfectly aligned with such a vision, and its author can unquestionably be counted among those, some more famous than others, who in the eighteenth century viewed Russia not only as a country to instruct but also as a place opening up new opportunities.

\section{Manoscritti}

Architektura cyvilnaja:

Mosca, RGADA, f. I8I. Rukopisnyj otdel biblioteki Moskovskogo glavnogo archiva Ministerstva inostrannych del, D. 258/463, ff. 48.

Breve trattato di architettura civile: Treviso, Biblioteca Comunale, MS. 393, ff. 67.

\section{Bibliografia}

Aikema 1984: $\quad$ B. Aikema, Pietro Della Vecchia, a Profile, "Saggi e memorie di storia dell'arte”, XIV, 1984, pp. 77-100, 171-206 (illustrations).

Aikema 1989:

B. Aikema, Della Vecchia, Pietro, in: Dizionario biografico degli italiani, XXXVII, Roma 1989, pp. 771-774.

"I "By beautiful garden compartments with parterre drawings as required by local usages, with flowers, fruits, and ornaments according to the particular region".

I2 "The so much needed and helpful geography".

I3 "Which no other human mind has ever collected but royal". 
Androsov 2003:

Balatri 2020:

Bobrova 1978:

Coronelli I697:

Di Salvo 1997:

Donaggio 2017:

Guzevič 2012:

Guzevič (forthcoming):

Lucchese 20II:

Pekarskij I862:

Pesenti 2003:

Rossi 2009:

Rossi 2010:

Šilkov I955:

Šmurlo 1903:
S.O. Androsov, Russkie zakazčiki i ital'janskie chudožniki v XVIII v., Sankt-Peterburg 2003.

F. Balatri, Vita e viaggi, a cura di M. Di Salvo, Alessandria 2020.

E.I. Bobrova (red.), Biblioteka Petra I: ukazatel'-spravočnik, Lenin$\operatorname{grad} 1978$.

Viaggi del P. Coronelli parte prima [-seconda]. Consecrati all'illustriss., ed eccellentiss. Signore conte Lazzaro Ferro di gloriosa memoria, e presentati all'illustriss., ed eccellentiss. Signore conte Giovanni di lui fratello, patritij veneti, \&c, per Gio. Battista Tramontino, in Venetia 1697.

M. Di Salvo, La missione di I. Čemodanov a Venezia (I656-I657): osservazioni e nuovi materiali, in: D. Rizzi, A. Shishkin (a cura di), Archivio italo-russo / Russko-ital'janskij archiv, Trento 1997, pp. 57-83.

V. Donaggio, Alessandro Dalla Via; un contributo all'arte incisoria veneta, "AFAT. Arte in Friuli Arte a Trieste", XXXVI, 2017, pp. 47-I3I.

D. Guzevič, Putevye zapiski Velikoj osoby (I697-I69g). Kritičeskaja istorija publikacii i problema avtorstva, Saarbrücken $20 \mathrm{I} 2$.

D.Ju. Guzevič, I.D. Guzevič, Knjaz'ja Dolgorukovy i problema avtorstva rukopisi "Architektura cyvil'naja", in: Petrovskoe vremja v licach 2020 (forthcoming).

E. Lucchese, Appunti per la conoscenza della pittura veneziana del Sei e Settecento in Istria e Dalmazia, "AFAT. Arte in Friuli Arte a Trieste", XXX, 20II, pp. 29I-304.

P. Pekarskij, Nauka i literatura v Rossii pri Petre Velikom, Sankt-Peterburg 1862 .

C. Pesenti, La trattatistica architettonica nel dialogo fra culture: Russia e Italia, in: M. Francioli, L. Tedeschi (a cura di), Dal mito al progetto. La cultura architettonica dei maestri italiani e ticinesi nella Russia neoclassica, I, Mendrisio 2003, pp. 255-268.

F. Rossi, Il principe Dolgorukov e i "Quattro Libri dell'Architettura" di Andrea Palladio nella Russia di Pietro il Grande, in: F.P. Di Teodoro (a cura di), Saggi di letteratura architettonica da Vitruvio a Winckelmann, I, Firenze 2009, pp. 267-284.

F. Rossi, Palladio in Russia: Nikolaj L'vov architetto e intellettuale russo al tramonto dei lumi, Venezia 2010.

V. Šilkov, Russkij perevod Vitruvija načala XVIII veka, "Architekturnoe nasledstvo", 1955, 7, pp. 89-92.

E. Šmurlo, Sbornik dokumentov, otnosjaščichsja k istorii carstvovanija imperatora Petra Velikogo, I. I693-I700 gg., Jur'ev 1903. 
Tic 1968:

Tolstoj 1992:

Vecchia 1729:
A.A. Tic, Neizvestnyj russkij traktat po architekture, in: T.V. Alekseeva (red.), Russkoe iskusstvo XVIII veka. Materialy i issledovanija, Moskva I968, pp. 17-3I.

P.A. Tolstoj, Putešestvie stol'nika P.A. Tolstogo po Evrope I697-I6gg, Moskva 1992 (Eng. transl.: The Travel Diary of Peter Tolstoi. A Muscovite in Early Modern Europe, transl. by M.J. Okenfuss, De Kalb [IL] 1987).

Problema della longitudine nautica risolto da Gasparo Vecchia veneto, Venezia 1729.

\section{Abstract}

Maria Di Salvo

Gasparo (Della) Vecchia, Architecture, and Russia

In the manuscript Architektura cyvilnaja (written in Venice in 1699), "Gasparo Vecchia" is mentioned by the Russian prince G.F. Dolgorukov as the author of a selection of Palladio's and other famous architects' texts, which were the sources Dolgorukov drew upon when writing his work. To my knowledge, Gasparo (Della) Vecchia has neither so far been properly identified nor his role studied in detail; in this paper, I try to shed some light on his relationship with Dolgorukov's text by analysing a manuscript penned by the Italian artist and entitled Breve trattato d'architettura civile, here investigated for the first time. I shall argue that in Venice Della Vecchia continued to be involved with Russians for some time: a letter dated 1715 and addressed to Peter the Great contains his proposal for a garden with didactic ends, thereby demonstrating that Della Vecchia was fully aware of the tsar's interests and goals.

\section{Keywords}

Gasparo (Della) Vecchia; G.F. Dolgorukov; Civil Architecture; Translation; Russia. 